\title{
Impact of corrosion processes in the basement level on the durability of the construction of large-panel buildings
}

\author{
Piotr Knyziak ${ }^{1,{ }^{*}}$, Piotr Bieranowski ${ }^{2}$ and Janusz R. Krentowski ${ }^{3}$ \\ ${ }^{1}$ Warsaw University of Technology, Al. Armii Ludowej 16, 00-637 Warsaw, Poland \\ ${ }^{2}$ University of Warmia and Mazury in Olsztyn, Oczapowskiego str. 11, 10-719 Olsztyn, Poland \\ ${ }^{3}$ Bialystok University of Technology, Wiejska str. 45, 15-351 Bialystok, Poland
}

\begin{abstract}
The paper presents results of research on the assessment of the corrosion progress level in structural elements of buildings made of largepanel technology. The symptoms of corrosion processes and the results of other authors research are presented.
\end{abstract}

\section{Background of the study}

The importance of proper maintenance and modernization of prefabricated buildings has been appreciated a long time ago. Published in 1978 the book [1] involved in all issues of maintenance of the building envelope. Already then noted that, despite the passage of about 20 years from the erection of the first buildings of the large-panel buildings, these buildings were not subjected to maintenance or repair. Similar conclusions were derived from the 2005-06 technical audits for buildings used for about 20 years [2].

Steel corrosion is the basic process of destroying reinforced concrete. The rate of this process depends on the possibility of penetration into the concrete of aggressive substances [3]. Correctly designed cover of the rods and appropriate tightness of the concrete ensure long-term use of the structure before the reinforcement corrosion [4]. The ability to protect reinforcing steel through a concrete cover depends on the $\mathrm{pH}$ of the concrete and the potential for corrosion-induced electrical charges (Figure 1). As a result of corrosion progress, the volume of corrosion products increases (Figure 2). On the surface of reinforced concrete elements, this process in the initial phase is manifested as cracks along the corroding reinforcement bars, and in the final phase as the concrete peeling and the direct exposure of the pretax.

The progress of corrosion processes in the construction of large-panel buildings is most noticeable in the cellars of buildings, because in most cases the surface of prefabricated and monolithic elements, both wall and ceiling remains unfinished with plaster. The condition of the joints of prefabricated panels and monolithic wreaths in the construction of largepanel buildings can be estimated only by point outcrops or signs of work (cracks, angles of rotation of the joints).

*Corresponding author: p.knyziak@il.pw.edu.p1 


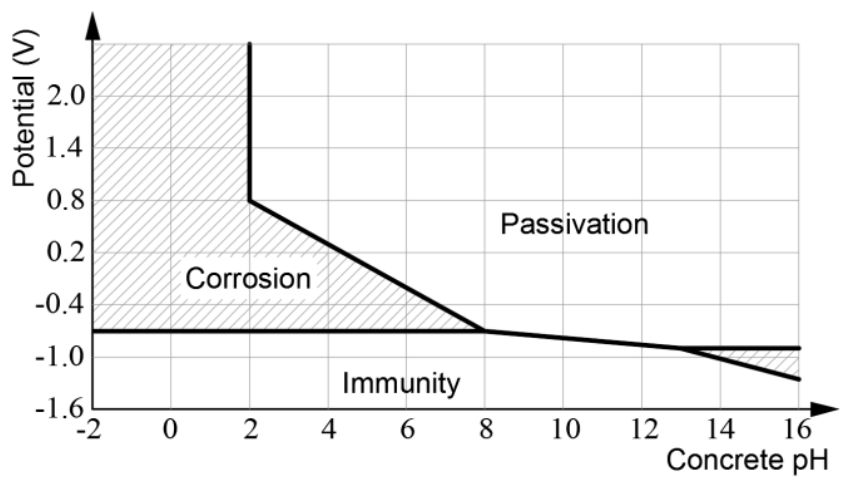

Fig. 1. Steel corrosion vs concrete $\mathrm{pH}$ value and potential

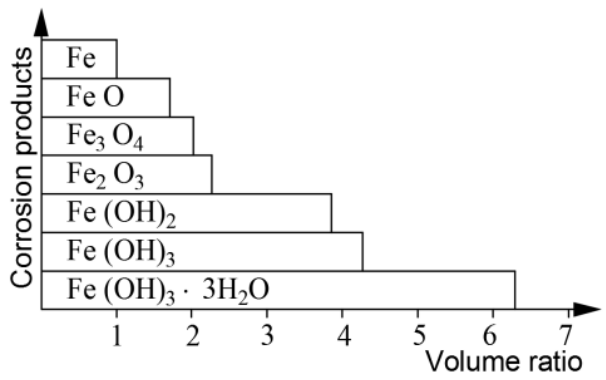

Fig. 2. Relative volume of steel and corrosion products [5]

\section{Risks of the corrosion indicated in the literature}

The results of conducted technical inspections and studies confirm lower level of manufacturing and embedding of sandwich panels [6,7]. The depth of the carbonation of concrete in facade plates found in outcrops does not exceed $5 \mathrm{~mm}$ [6]. The report of these studies indicates the moisture of mineral wool in winter-spring period. In this case increased humidity led to pitting corrosion of hangers (members connecting layers of cladding panels). After 8 years of operation, the depth of corrosion pits reached $0.2 \mathrm{~mm}$. High humidity is also due to the possibility of an incomplete seasonal evaporates of moisture.

A major problem [8] is the quality of prefabricated joints. The disadvantages are both the partial absence of reinforcement and the cavities in cross section of the elements, and a danger of corrosion of the reinforcing bars in RC sections. Chemical analysis of the amount of aggressive ions in the aspect of impact on concrete and steel, according to chemical quantitative analysis, showed that concrete from samples taken in joints and prefabricated panels contained an average of $36 \%$ of soluble in acid parts. Samples exposed to more intense external atmospheric agents exhibited 30\% soluble fraction. Chloride and sulfate ions in the samples were not present in increased quantity. The $\mathrm{pH}$ of the samples was in the range $11.6 \div 12.1$.

Characteristic damage in the context of corrosion, also include damage and cracks of the finishing layer. They occur on the surface of the element, rarely in the area of the joints. At work [9] the measured crack width was in the range of $0.5 \div 3.0 \mathrm{~mm}$. There have been also cases of improper plate assembly where the displacement of the joined elements was within 2 to $4 \mathrm{~cm}$. The occurrence of damage of the cladding panels has an explicit effect on corrosion of hangers joining finishing and structural parts of precast elements. 
Non-invasive testing methods are widely used in diagnostics [10]. They should be conducted in stages: stage I - global diagnostics - localization of building structures potentially threatened with destruction (e.g. thermovision); stage II - conducting research in specific locations in the context of the occurrence of destruction (e.g. radiological, electrochemical methods); - stage III - sublocal diagnosis - identification of damage: type, intensity and extent of impact). Especially useful is the thermovision, allow on identification of places of cooling on the building's elevation, thus the critical points in the context of excessive moisture, which together with the chemical composition of building materials is an environment and a medium suitable for the development of molds. The greatest moisture can be found in the cellar walls. This is often caused by badly profiled bands and cracks in the plinth zones, as well as the destruction of insulation in the cellar floor. Conduct inspection, allows to identify this type of damage. It can also often notice incorrectly performed installation repair work, such as the careless execution of installation passes between and through precast elements in the horizontal and vertical plane.

The non-destructive electrochemical method used in [10] allowed to determine the probability of corrosion of reinforcement in reinforced concrete elements. It has been found that the probability of corrosion of reinforcement reaches $95 \%$ in the exterior walls to a height of about $0.5 \mathrm{~m}$ above the floor. Up to $1.30 \mathrm{~m}$ this value reached $50 \%$. In the basement's internal walls up to $1.30 \mathrm{~m}$ above the floor, the probability of corrosion was estimated at $5 \%$.

\section{Results of technical inspections in years 2005-06 and 2016-17}

In the years 2005-06, technical inspections were carried out in 95 buildings $[11,12]$ and in 2016-17 in 110 buildings. Their results are reported below.

One of the basic processes to be checked during technical inspections is corrosion of steel. The main task of technical inspections is to check the progress of corrosion in the elements of the building, because most often they are components or installations that have been subject to this process from the beginning (e.g. tinplate). Regarding to reinforced concrete elements, cracks control and corrosion symptoms as discoloration and cracking of the reinforcement cover should be observed. Damage points should also be indicated to protect them. Despite the many annual and five-year inspections in most buildings, many of the reinforced concrete elements in cellar level in multi-family buildings remain not protected since construction moment (Figure 3).
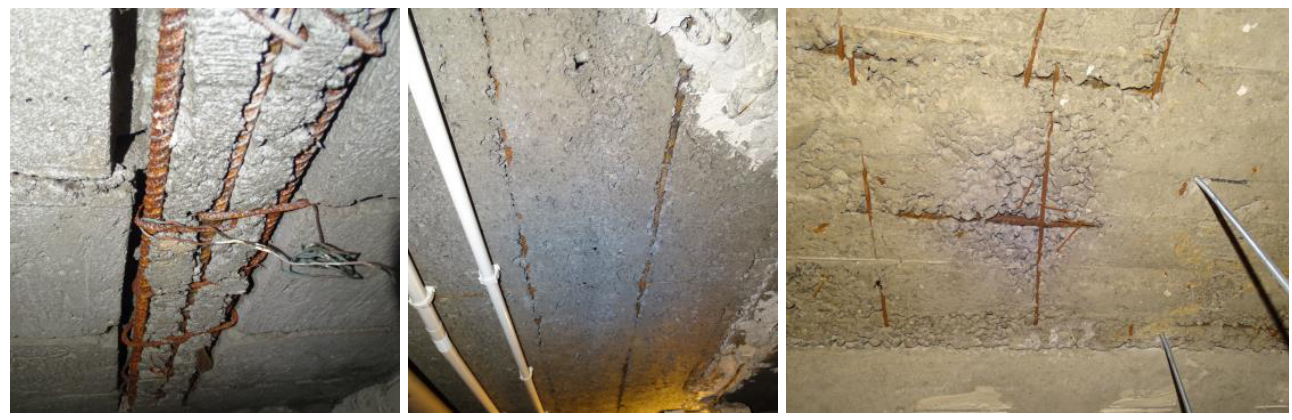

Fig. 3. Reinforcement not protected since construction moment (photos by Piotr Knyziak, 2016)

There are no symptoms of poor operation of these components, although the reinforcement steel has no corrosion protection on site and the requirements for the transmission of stresses between steel and concrete are not met. In most of the cases they 
were small fragments ceilings made of monolithic construction or parts of basement walls (elements using a low bearing capacity). In a few cases it was possible to find a precast elements with improperly made reinforcement cover - visible abnormal thickening of concrete around the bar located just off the surface of the element, or even less frequently, bars visible on the surface of the precast elements.
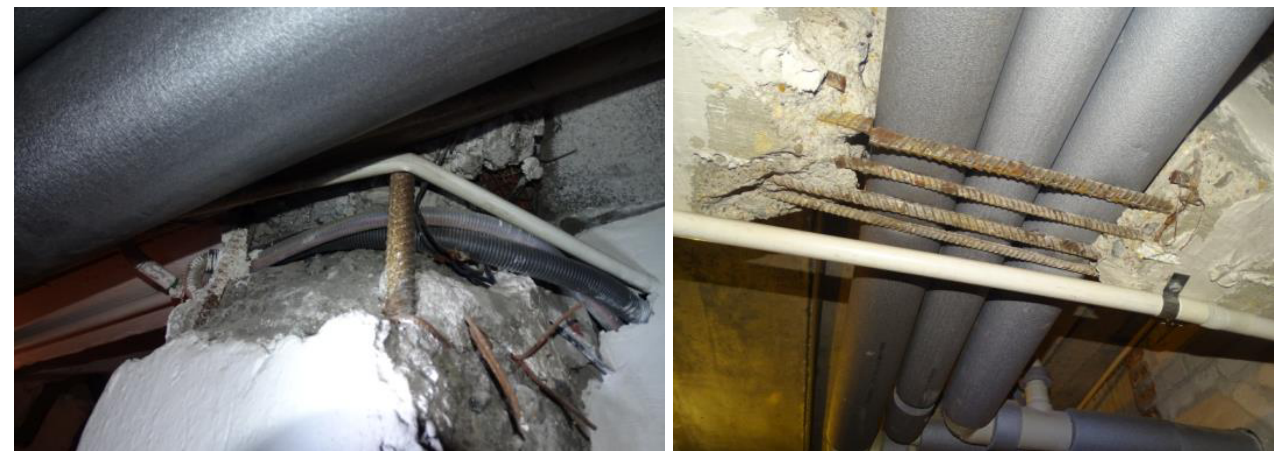

Fig. 4. Reinforcement exposed during installation work and not secured (Piotr Knyziak, 2016)

In many cases, installers performing upgrades made breakthrough of reinforced concrete elements, including exposing the reinforcing bars and the cutting of the bars (Figure 4). Mostly damaged are the external parts of the walls in the basement corridors and the lintel sections of the prefabricated sections with a communication hole. In some cases, the damage is covered with new mortar or putty, probably lacking the protective properties in relation to steel. In four of the tested buildings the basement ceilings were insulated (Figure 5), which prevented the cracks and corrosion control of the slabs. They have also been recorded cases of white paint on the basement, but paint with the addition of gypsum.
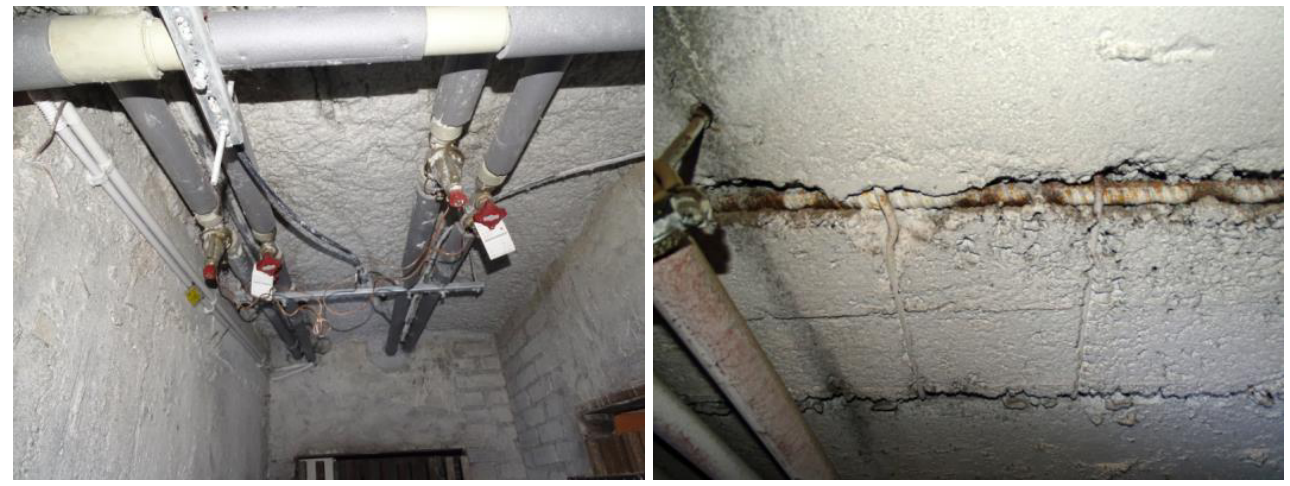

Fig. 5. Insulation of ceiling and ceiling with exposed reinforcement painted with the addition of gypsum (photos by Piotr Knyziak, 2016)

During the inspection of buildings were observed a low level of corrosion of the most parts of the exposed reinforcement and other steel elements. Bars not concreted during construction found in the basement level in concrete elements made on site, in almost all cases, were covered only with a thin corrosion coating, and often on a part of the surface of the rod there was no corrosive attack at all (Figure 6). 

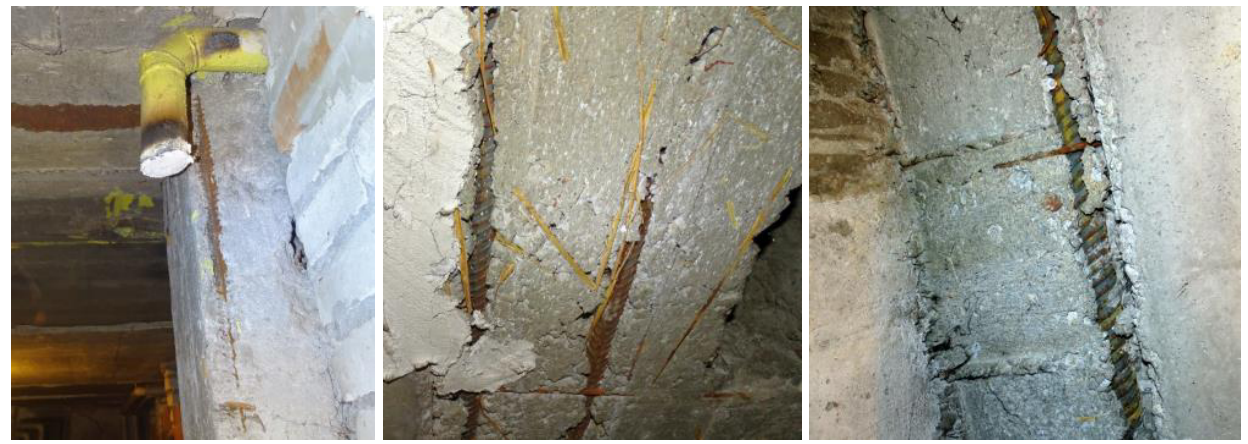

Fig. 6. No corrosion on reinforcement surface (photos by Piotr Knyziak, 2016)

Basement conditions can be considered as unfavorable to the development of corrosion, due to the low humidity of the air, which is heated practically throughout the year by hot water circuits and in winter also by central heating. In many buildings there are incidental flooding of cellars from the rain water installation, after the downpour, but not little impact on the progress of corrosion in the current period of use.

During the technical inspections of 110 prefabricated buildings particular attention was paid to the correctness of prefabrication, the occurrence of symptoms of too thin cover of reinforcement bars, the level of corrosion of visible sections of reinforcing bars. The results of the technical inspections are summarized (Figure 7) by the following indications: 0 elements without symptoms of poorly made cover and without symptoms of low thickness of the cover, 1 - symptoms of low thickness of reinforcement cover in the elements, 2 symptoms of corrosion of reinforcement under the cover, 3 - cover partial deficiencies, bars partially corroded, 4 - cover partial deficiencies, rods coated by low corrosion, 4 - cover partial deficiencies, rods coated by high corrosion, 6 - insulation of elements that do not determine the level of corrosion.

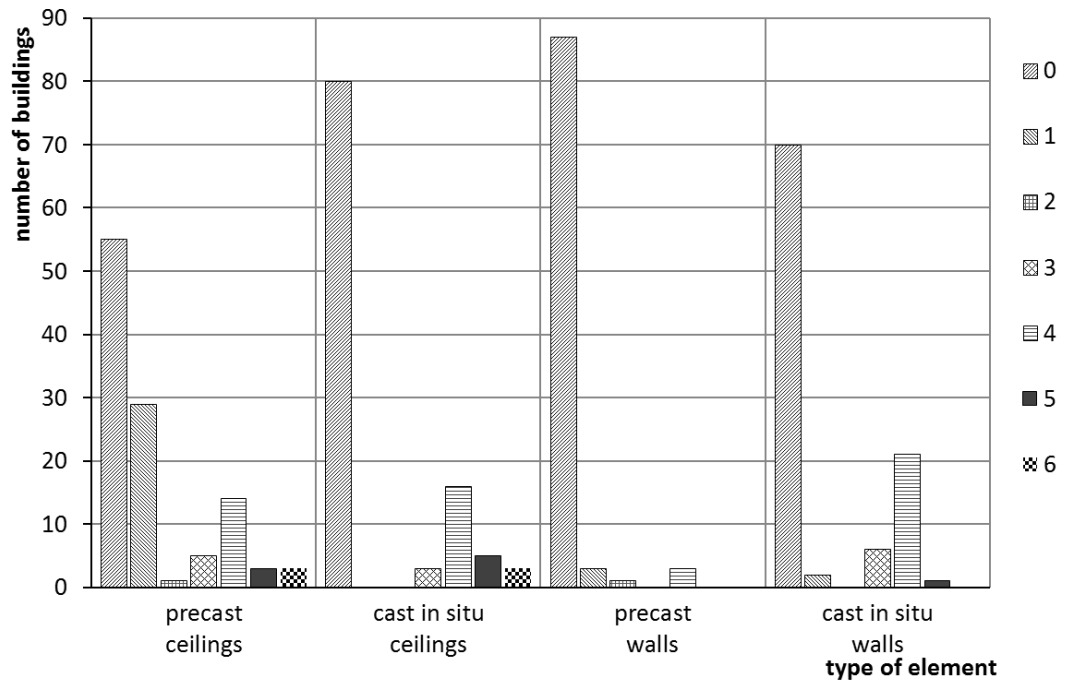

Fig. 7. Shortcomings and corrosion ratio in elements (data collected by Piotr Knyziak)

Results of technical inspections indicate that in most of the reviewed buildings, no cases of improperly constructed prefabricated or monolithic elements were found. In most cases, there are also no signs of corrosion under the concrete cover. 


\section{Summary}

Evaluation of the technical condition based on the indications visible on the surface of the elements makes the most sense. It allows quickly in many buildings to check whether corrosion has crossed the initial stage. Taking into account the results of the technical inspections and the research on carbonation of reinforcement cover, it can be concluded that under very favorable conditions in prefabricated buildings, so made of higher classes of concrete, very low corrosion progress and technical wear can occur. Should be the rule to repair damaged elements without delay and periodically control the condition of buildings elements.

Previous author studies $[11,12]$ and the wide current work allow concluding that is possible long-term safe use of prefabricated buildings. Durability of buildings properly exploited, who are under constant supervision is estimated as comparable to buildings made of monolithic technology.

\section{References}

1. W. Konecki, J. Sitkowski, A. Ulatowski, Remonty budynków mieszkalnych wznoszonych metodami uprzemystowionymi. Przegrody zewnętrzne (Arkady, Warszawa, 1978)

2. P. Knyziak, Trwate metody naprawcze w obiektach budowlanych, 206 (Dolnośląskie Wydawnictwo Edukacyjne, 2015)

3. A. M. Neville, Wtaściwości betonu (Polski Cement, Kraków, 2000)

4. M. Jaśniok, A. Zybura, Przegląd Budowlany 1 (2007)

5. S.J. Han et al., Constr. and Build. Mat. 54, 572 (2014)

6. Z. Ściślewski, Mat. Bud. 11, 3 (2004)

7. J. Krentowski, R. Tribiłło, Przeg. Bud. 2, 34 (2008)

8. M. Wójtowicz, T. Możaryn, Konferencja Naukowo-Techniczna: Awarie Budowlane 2013, 889 (2013)

9. W. Ligęza, Konferencja Naukowo-Techniczna: Awarie Budowlane 2007, 741 (2007)

10. J. Sobczak-Piąstka, Konferencja Naukowo-Techniczna: Awarie Budowlane 2015, 695 (2015)

11. P. Knyziak, Analiza stanu technicznego prefabrykowanych budynków mieszkalnych za pomoca sztucznych sieci neuronowych $(\mathrm{PhD}$ thesis. Warsaw University of Technology, Warsaw, 2007)

12. P. Knyziak, M. Witkowski, Inż. i Bud. 12, 639 (2007) 